\title{
INFORMING CANADIAN INNOVATION POLICY THROUGH A DECOLONIZING LENS ON INDIGENOUS ENTREPRENEURSHIP AND INNOVATION
}

\author{
MERLI TAMTIK \\ UNIVERSITY OF MANITOBA \\ |
}

\begin{abstract}
While Indigenous entrepreneurship is associated with significant economic promise, Indigenous innovation continues to be invisible in Canadian policy contexts. This article examines how Indigenous entrepreneurial activities are framed in government policy, potentially leading to another wave of active exploitation of Indigenous lands, peoples, and knowledges. The article first discusses the concepts of Indigenous entrepreneurship and innovation through a decolonizing lens, drawing links to education. Then, it provides a set of rationales for why governments need to re-think and prioritize Indigenous entrepreneurship. Next, it maps the current federal government initiatives in this policy sector. Drawing from the Indigenous entrepreneurship ecosystem approach (Dell \& Houkamau, 2016; Dell et al., 2017), the article argues that a more comprehensive policy perspective guiding Indigenous entrepreneurship programs should inform Canadian innovation policy. Individual voices from 13 Indigenous entrepreneurs in Manitoba point to three core issues: (a) relationships with the land and the community; (b) the relevance of (higher) education and training; and (c) the importance of cultural survival and self-determination. The article makes an argument for a systemic decolonizing change in how Indigenous innovation is approached in government policy and programs, supported by the work of higher education institutions ${ }^{1}$.
\end{abstract}

Keywords: Indigenous entrepreneurship, decolonization, ecosystem, innovation, policy

\section{Résumé}

Alors que l'entrepreneuriat autochtone est associé à une promesse économique importante, l'innovation autochtone est toujours invisible dans le contexte des politiques publiques canadiennes. Cet article examine la manière dont les activités entrepreneuriales autochtones sont encadrées dans les politiques publiques, laquelle risque de provoquer une autre vague d'exploitation des terres, des peuples et des connaissances autochtones. Dans un premier temps, l'article discute des concepts d'entrepreneuriat et d'innovation autochtones sous l'angle de la décolonisation et établit des liens avec l'éducation. Ensuite, il fournit un ensemble de justifications expliquant pourquoi les gouvernements doivent repenser et prioriser l'entrepreneuriat autochtone. Enfin, il recense les initiatives actuelles du gouvernement fédéral dans ce secteur. S'inspirant de l'approche écosystémique de l'entrepreneuriat autochtone (Dell et Houkamau, 2016; Dell et al., 2017), cet article soutient qu'une politique publique plus complète pour orienter les programmes d'entrepreneuriat autochtone devrait éclairer la politique d'innovation canadienne. Les voix individuelles de 13 entrepreneurs autochtones du Manitoba permettent de souligner trois enjeux fondamentaux : 1) les relations avec la terre et la communauté; 2) la pertinence de l'enseignement (supérieur) et de la formation; 3) l'importance de la survie culturelle et de l'autodétermination. Cet article plaide en faveur d'un changement décolonisant systémique dans la façon dont l'innovation autochtone devrait être abordée dans les programmes gouvernementaux et les politiques publiques, avec l'appui des établissements d'enseignement supérieur.

Mots-clés : entrepreneuriat autochtone, décolonisation, écosystème, innovation, politique publique

\section{Introduction}

Indigenous entrepreneurship has started to gain significant momentum in the context of Canadian eco- nomic development. In 2016, Indigenous peoples and their businesses contributed $\$ 32$ billion dollars to the Canadian economy (Canadian Council for Aboriginal Business, 2016). Reaching a \$100-billion-dollar Indige- 
nous economy by 2023 has become an achievable and realistic goal (see Indigenomics Institute, n.d.). Policy documents have emphasized the significant economic promise of Indigenous entrepreneurship for the Canadian digital economy (Canadian Council for Aboriginal Business, 2016; Indigenous Tourism Association of Canada, 2019), tourism industry (Indigenous Tourism Association of Canada, 2019), international trade (Global Affairs Canada, 2019) and beyond. Consequently, we are witnessing a shift in the dominant narrative of Indigenous peoples as permanent aid-receivers to Indigenous peoples as catalysts for exciting new partnerships, investment, and long-term economic growth for Canada. The core questions become, on whose terms and how? Can the elected Liberal government continue to facilitate Indigenous entrepreneurial and innovation activities in a way that does not constitute another wave of active colonization and exploitation of Indigenous lands, peoples, and knowledges but instead is grounded in Indigenous worldviews and self-governance? What role does (higher) education play in this process?

This article aims to contribute to the discussions on Indigenous entrepreneurship and Indigenous innovation by highlighting the experiences of Indigenous entrepreneurs, pointing to the need for more balanced policy approaches, where higher education institutions have an important role to play. The article is informed by the findings of an empirical study conducted in 2018-2019 among 13 Indigenous entrepreneurs operating across the province of Manitoba in both urban (Winnipeg) and rural (Churchill, Gillam, Thompson) contexts. Manitoba is the province with the highest Indigenous population share (17\%) among all Canadian provinces, with an increasing number of Indigenous youth entering schools and post-secondary institutions (Statistics Canada, 2016). Study participants self-identified as Indigenous, were operating off-reserve, and were not part of a First Nations band. These individuals-and in several cases their families-were involved in various forms of smallscale entrepreneurial activities, including architecture and interior design, tourism, hunting, trapping, handicrafts, bed and breakfast services, and construction businesses. They had incorporated Indigenous cultural knowledge into their activities. Narrative inquiry was applied as a method to allow Indigenous participants to become active collaborators in the research, taking power and ownership of the process while sharing their personal stories (Donald, 2009; Lowan-Trudeau, 2012).
Insights from this fieldwork provide important empirical evidence on Indigenous entrepreneurship experiences in Canada and will help to inform policy approaches of administrators located across education and government spaces.

\section{What Is Indigenous Entrepreneurship and Innovation?}

Indigenous entrepreneurship as a distinct phenomenon has drawn significant academic interest from scholars in Canada and beyond (e.g., Curry et al., 2009; Hindle \& Lansdowne, 2005; Imas et al., 2012; Kayseas et al., 2006). This literature suggests that Indigenous entrepreneurship as a concept differs from the Western notion of entrepreneurship. The mainstream (Western) paradigm of entrepreneurship emphasizes private profits, economic prosperity, and individual gain (Schumpeter, 1934; Van Praag \& Versloot, 2007). Notions such as efficiency, production, and maximization of growth are instrumental measures for entrepreneurial success.

Researchers have noted that Indigenous entrepreneurship builds on its own concepts of epistemology, philosophy, and scientific and logical validity (Daes, 1994; Wuttunee, 2004). Hindle and Lansdowne (2005) defined Indigenous entrepreneurship broadly as the "creation, management and development of new ventures by Indigenous people for the benefit of Indigenous people" (p. 132). Authors agree that Indigenous entrepreneurship should include components of Indigenous culture, feature interactions with the entrepreneurs' cultural community, and entail a wide range of benefits that go beyond individual economic profits (Colbourne, 2017; Peredo \& Chrisman, 2006; Sengupta et al., 2015). Those benefits typically include social, political, cultural, and economic advantages for the entire community (Colbourne, 2017; Peredo \& Chrisman, 2006). Scholars also describe enhanced social relationships and emerging interdependencies in the community, new cultural and spiritual understandings, and a resurgence of beliefs and practices embedded in a traditional territory or land (Anderson et al., 2006; Colbourne, 2017; Sengupta et al., 2015). Following this logic, traditional hunting and fishing activities can be considered a form of Indigenous entrepreneurship if those help to reinforce cultural and spiritual connections and strengthen the livelihood of a community. Anderson et al. (2006) argued that an Indig- 
enous individual (or corporation) who is simply a business entrepreneur with a singular goal of maximizing economic profits should not be included in the definition of an Indigenous entrepreneur. In this article, I regard Indigenous entrepreneurship as an activity that includes an Indigenous cultural component, decision-making autonomy (self-governance), and a mixture of technical and cultural skills (Hindle \& Lansdowne, 2005; Hindle et al., 2007; Lindsay, 2005; Peredo et al., 2004).

Indigenous entrepreneurship activities can take on various forms ranging from individual small start-ups and family businesses to larger band-governed resource industries. Peredo and Chrisman (2006) proposed the theoretical model of community-based enterprise (CBE) to understand Indigenous entrepreneurship, where the whole community acts corporately to pursue its shortand long-term economic and social goals. Such community-based entrepreneurship is evident in on-reserve Indigenous entrepreneurship, whereby land used for entrepreneurial activities is community-owned and managed by band councils (in a Canadian context) (Curry et al., 2009; Kayseas et al., 2006). Authors have noted that band-governed First Nations communities face unique challenges as they may get tangled in the politics surrounding the dilemma of whether to reinvest the profits back into the community or sustain employment growth (Curry et al., 2009). Authors have also emphasized the importance of community-based decision-making, self-governance, strong leadership, and transparency in the success of such operations. Overall, the perspective of CBE is helpful, as it demonstrates the need to focus on the ecosystem of local cultures, values, and complex relationships surrounding Indigenous entrepreneurship.

In the academic literature, the concepts of entrepreneurship and innovation are closely intertwined. Innovation is typically defined as the creation, development, and implementation of a new product, process, or service, and it is intrinsically related to the idea of combining new or existing knowledge in a novel way (Borrás \& Edquist, 2014). Indigenous innovation has distinct features that highlight its connection to heritage and the entrepreneurs' (re)learning of their Indigenous cultural ways of knowing and being. Innovation in Indigenous contexts is understood as "looking back" and not necessarily as "looking forward" (Hindle \& Lansdowne, 2005, p. 133). Indigenous innovation often denotes healing and recovery from the colonial past. Sengupta et al. (2015) suggested that Indigenous innovation can be understood as creating shifts in power dynamics between Indigenous and non-Indigenous people, thus serving as a form of decolonization. Indigenous innovation differs conceptually from the mainstream understanding of innovation, which is seen as the commercialization of products and services. Indigenous innovation is often experienced as a process of learning, applying a decolonizing lens, and challenging systemic oppressive structures in society. Indigenous innovation does not often fit the mainstream framing of innovation and may therefore be viewed as somehow lesser or not relevant (Tedmanson et al., 2012), reinforcing colonial perspectives of what counts as a valid and acceptable form of innovation.

Education plays a central role in supporting Indigenous entrepreneurship and innovation. First, entrepreneurial capacity is grounded in skills, experience, and education (Hindle \& Moroz, 2010). Education provides formal and informal knowledge that is needed to navigate the administrative aspects of the entrepreneurial process. Second, viewing Indigenous innovation through a decolonizing lens can be achieved by developing critical thinking skills and learning to value and normalize Indigenous knowledges and epistemologies. As such, education provided through higher education institutions is crucial in creating a foundation for this broader societal shift, educating both Indigenous and non-Indigenous individuals to problematize the hegemonic colonial perspective shaping our society.

Scholars agree that Indigenous entrepreneurship and innovation are highly context dependent (Croce, 2017; Gallagher, 2015), making them a complex puzzle to address through policy. Despite governmental efforts to support Indigenous entrepreneurship, an underlying divide on how entrepreneurship and innovation may manifest itself, particularly through challenging systemic structures and dominant power, has contributed to the failure of many policy initiatives in various countries (Gallagher 2015; Shoebridge et al., 2012). The Canadian policy realm is no different. The Canadian federal government has addressed the topic of Aboriginal entrepreneurship in several of its policy documents (Government of Canada, 1989, 2009), yet the emerging theme in these documents reinforces the narrative of economic prosperity, without carefully considering the paradigmatic differences associated with the mainstream and Indigenous entrepreneurship and innovation. 


\section{Why Should Ind igenous Entrepreneurship Have the Immediate Attention of Canadian Government Policy Makers?}

The global race for economic competitiveness has pushed our societies into an era of major environmental challenges that demands reimagining the values and knowledges with which we operate. The failure of neo-liberal (market-driven) rigid government approaches to development has led to a search for alternative ways of policy and practice. Indigenous knowledge and innovation systems can offer a way forward (Agrawal, 1995; Battiste \& Youngblood, 2000). Indigenous perspectives and ways of knowing are associated with more sustainable ways of addressing the diverse social and economic needs of peoples across the globe (Huaman, 2017; Wuttunee, 2004). Furthermore, attention toward Indigenous innovation, understood through a decolonizing lens, would serve as an integral component of reconciliation, supporting existing government policy and practice in this journey. There are a number of arguments, all interconnected, that should convince government policy makers to reimagine Indigenous entrepreneurship in their policy and programmatic decisions.

\section{The Argument of Economic Growth}

Within the next decade, Indigenous businesses will play a fundamental role in driving economic growth in Canada. The number of Indigenous entrepreneurs in Canada has nearly tripled in the last 20 years, from 20,195 in 1996 to 54,255 in 2016 (Statistics Canada, 2016). The current contribution of Indigenous entrepreneurs and businesses to the Canadian economy is already noteworthy ( $\$ 32$ billion in 2016) (Canadian Council for Aboriginal Business, 2016). The Indigenous tourism industry alone recorded a $\$ 1.7$ billion contribution toward annual GDP in Canada in 2017 with the goal of increasing this amount to $\$ 2.2$ billion by 2024 (Indigenous Tourism Association of Canada, 2019). The push toward advocating for a $\$ 100$ billion Indigenous economy by 2023 in Canada has taken off (see Indigenomics Institute, n.d.). As Indigenous businesses continue to grow, so do the employment opportunities, wages, and salaries that are attached to significant contributions to the Canadian government through tax revenues. Emphasizing these statistics would create a strength-based approach to Indigenous entrepreneurship and gradually change the dominant narrative around problems and deficits associated with Indigenous peoples. Being self-sustaining and helping to create employment opportunities is seen as a core factor in Indigenous community empowerment and self-determination (Pinto \& Blue, 2017).

\section{The Argument of Changing Demographics}

Statistics Canada (2019) reported that, in 2016, there were 1,673,785 Indigenous people in Canada, accounting for $4.9 \%$ of the total population; it is estimated that in less than two decades, by 2036, the Indigenous population is likely to exceed 2.5 million persons. The Indigenous population is also nearly a decade younger than the rest of the population in Canada. In 2016, the median age in years for the Indigenous population was 29.1, but 41.3 for the non-Indigenous population (Statistics Canada, 2019). This means that more than 600,000 Indigenous youth will come of age to enter higher education institutions and then the labour market within the next decade. Higher education institutions need to make sure the focus of their educational programs is relevant to Indigenous experiences. For example, First Nations youth living on reserve experience significantly worse employment opportunities than any other identity groups, with an employment rate of only $17.1 \%$ and an unemployment rate of $40.8 \%$ (National Indigenous Economic Development Board, 2019). Lower high school completion rates are strongly correlated with poorer economic outcomes, including lower income levels (National Indigenous Economic Development Board, 2019). Suicide rates among First Nations youth (aged 15 to 24 years) across Canada are five to six times higher than among non-Indigenous youth (Kirmayer et al., 2007). These statistics are striking. A strategic focus on (higher) education and skills training is essential in order to create awareness around the various career opportunities available to Indigenous youth, providing them with meaningful and viable employment. 


\section{The Argument of Indigenous Rights}

The Canadian federal government has committed to the advancement of the reconciliation process with Indigenous peoples based on the recognition of Indigenous rights, self-determination, self-governance, and cooperation (Government of Canada, 2018). Indigenous peoples in Canada have the protection of their Aboriginal and treaty rights under the Canadian constitution Section 35 and Canada's endorsement of the United Nations Declaration of the Rights of Indigenous Peoples (UNDRIP) in 2016 (UNDRIP, 2007). Both documents are somewhat controversial, as there are sentiments that, by accepting the Constitution, Canada overrides nation-to-nation treaty agreements with Indigenous peoples, which diminishes the self-governance aspect grounded in Indigenous rights. While not yet legally binding across Canada, British Columbia has introduced a bill to align its laws with the UNDRIP (Bill-41: Declaration on the Rights of Indigenous Peoples, 2019). The Canadian federal government has expressed its commitment to UNDRIP by developing, in collaboration with Indigenous peoples, a document that lists the rights and responsibilities of both the federal government as well as Indigenous peoples in a relationship defined as "cooperative federalism" (Department of Justice, Canada, 2018, p. 9). This is a shift away from using the Indian Act, passed in 1876, as a sole reference to determine the governance of most First Nations in Canada. The point about respectful business ventures was first articulated in the Truth and Reconciliation Commission's Calls for Action (\#92 section on business and reconciliation) in 2015. These documents laid a rights-based foundation for working with Indigenous peoples and made a crucial attempt to protect Indigenous communities from resource extraction through the economic, entrepreneurial, and development projects that have exploited Indigenous lands for centuries.

\section{The Innovation Argument}

Despite significant monetary allocations, tax incentives, and a solid research system, recent policy reports have referred to a continuous underperformance in Canada's innovation agenda, pointing to Canada as an "innovation under-achiever" (Expert Panel on the State of Science and Technology and Industrial Research and Development in Canada, 2018; Schwanen, 2017, p. 1). Scholars have emphasized that innovation is ultimately a social process that emerges not as a result of increased financial resources but from entrepreneurial collaboration and learning practices that build on already existing knowledge (Borrás \& Edquist, 2014; Lundvall, 2009). Therefore, if Canadian innovation were approached through the decolonizing lens that forms the essence of Indigenous innovation, instead of from a commercialization perspective, it would be necessary to challenge, with the help of higher education institutions, the underlying institutional structures and norms that perpetuate colonial perspectives in our society. Such an approach would speak to the social justice movements emerging across the globe and align with Canadian higher education institutions' long-standing quest for diversity, equity, and inclusion.

\section{What Is the Current State of Indigenous Entrepreneurship in the Federal Initiatives?}

There are important developments, driven by the federal government, that have laid a promising foundation for how Indigenous innovation will be addressed in the future. As already noted, the most dominant support mechanism has been financial assistance, which has been provided to Indigenous entrepreneurship activities through various government loans and grants. For example, the Government of Canada (2019a) reported that, since 2015, $\$ 320$ million in capital has been committed to help Indigenous small and medium businesses across the country. The Federal Budget 2019 highlighted support for Indigenous entrepreneurs through the Indigenous Growth Fund and the expansion of the Aboriginal Entrepreneurship Program with $\$ 17$ million over three years (Government of Canada, 2019a). The budget document also listed targeted support for Indigenous youth of $\$ 3$ million over five years through Futurpreneur Canada, a national non-profit organization committed to helping young entrepreneurs. While this support has resulted in some success, ${ }^{2}$ various reports by Indigenous organizations have pointed out difficulties in accessing those government funds, a lack of knowledge about where and how to apply for financing, and various eligibility restrictions for different types of funding (National Aboriginal Capital Corporation, 2017; National Indigenous Economic Development Board, 2019). 
There has been an effort to increase Indigenous participation in decision-making processes regarding economic development, especially decisions involving natural resources. In 2010 the federal government launched The Strategic Partnership Initiative, which focuses on the participation of Indigenous communities in restoring their control of and access to Indigenous lands (Government of Canada, n.d.). Anderson et al. (2006) noted that the Canadian federal government has shifted its position from contesting Indigenous claims to land and resources toward negotiations. Patzer (2019) noted that, while the Crown has a legal obligation to a meaningful process of consultations with Indigenous groups, there is no absolute obligation for the government to arrive at agreement. In fact, there are still cases where the courts have placed limits on reconciliation and exercised legal governance over the decolonizing aspirations of Indigenous peoples in Canada.

The most recent change in government initiatives has concerned organizational restructuring within the federal government. In 2017 two new units were established: (a) Crown-Indigenous Relations and Northern Affairs Canada (focusing on governance and relationship building, including financial arrangements affecting Indigenous businesses and entrepreneurs); and (b) Indigenous Services Canada (supporting skills, training, education, and employment-related matters). Through this reorganization, the skills and training component, essential for Indigenous peoples entering the labour market, has been addressed in a more straightforward manner. This organizational change anticipates a shift away from the governments' dominant approach of purely "delivering government programs" toward building Indigenous-led institutions and Indigenous-led governments (APTN National News, 2017, n.p.). The latter is truly a laudable development, if the issue of Indigenous entrepreneurship is to be approached in a more comprehensive and systematic way that moves beyond a narrow focus on isolated pockets of financial support.

While Indigenous innovation is being addressed through various financial means, the policy side of it is still weak. Aboriginal entrepreneurship was included in the Federal Framework for Aboriginal Economic Development (Government of Canada, 2009), a successor to the Canadian Aboriginal Economic Development Strategy (Government of Canada, 1989) policy document. Developed under Stephen Harper's Conservative government, this document aims to guide the federal de- cision-making process when the government initiates new programs for Aboriginal economic development. It completely ignores the components of culture, cultural diversity, and Indigenous ways of knowing. Not much different is Canada's innovation policy (2019), where Indigenous entrepreneurs are addressed in passing as one of the groups facing barriers to starting and growing their businesses (Government of Canada, 2019b).

These examples describe some of the steps taken by the federal government in relation to Indigenous entrepreneurship activities. There seems to be an indication that the government is moving away from the dominant deficit-based mindset toward a relationship-based approach when working with Indigenous peoples. Nevertheless, there is still much more to do. There is a clear need for a comprehensive, context-specific, and decolonizing policy approach to be developed in collaboration with Indigenous communities. Such an approach would more coherently support the activities of Indigenous entrepreneurs and innovators and focus on the systemic socio-economic barriers that Indigenous entrepreneurs are facing, with education as the underlying foundation.

\section{How Could an Indigenous Ecosystem Lens Inform a Decolonizing Approach in Government Policy?}

The weakness of current governmental approaches to Indigenous innovation is the emphasis on program-based policies that feature economic benefits without leaving much room for the socio-cultural, community-building aspects or alternative framings of innovation. An entrepreneurial ecosystem approach could provide a useful lens that would allow a more comprehensive approach to supporting Indigenous entrepreneurship. This approach focuses on creating the external environment that supports the individual and on the individual's response to its environmental context. Stam (2015) defined an entrepreneurial ecosystem as "a set of interdependent actors and factors coordinated in such a way that they enable productive entrepreneurship" (p. 5). This definition acknowledges a systematic approach, focusing on the interconnectedness of social and cultural elements that support entrepreneurial activities (Isenberg, 2010; Manimala \& Wasdani, 2015; Roundy et al., 2018). Some 
examples of such actors would be governments, family members, and skilled workers, and the factors could be geographical location, access to education (schools and universities), and availability of government loans. Darisi and Watson (2017) acknowledged the value of the entrepreneurial ecosystem in the Canadian context, noting that support for system-building initiatives (especially those for youth entrepreneurs), such as facilitating networks, considering strategic partnerships, and forming targeted mentorships, can all strengthen the social, financial, and business infrastructure required to support youth to succeed as entrepreneurs.

The work of scholars situated in Maori cultures in New Zealand has led to the development of an Indigenous entrepreneurial ecosystem concept (Dell \& Houkamau, 2016; Dell et al., 2017) that might be useful in guiding our understanding of Indigenous entrepreneurship in Canada. The concept of an Indigenous entrepreneurship ecosystem draws on Indigeneity as its source of inspiration and innovation. It focuses on the collective wellbeing of Indigenous peoples in their community and features sustainable ways of doing business (Warren et al., 2017). Dell and Houkaumau's (2016) work in Maori cultures has led them to deploy the concepts of fire-seeking and fire-keeping to understand the complexity of Indigenous entrepreneurship. This perspective provides a decolonizing culture-informed way of focusing on entrepreneurship through dual relationships. It has both an inward focus (advancing Indigenous cultural imperatives and nurturing Indigenous communities) and an outward focus (engagement with external/non-Indigenous commercial interests). Fire is a core symbol in Indigenous cultures associated with cleansing and renewal as the ashes from the fire lead to new life, ideas, and knowledge. The concept of fire-seeking denotes Indigenous entrepreneurial self-determination and empowerment by removing barriers and constraints to Indigenous engagement with the wider world. Often fire-seeking initiatives are collaborations, led by Indigenous community, between public and private institutions, education providers, and enterprises, geared toward encouraging Indigenous participation. The fire-keeping metaphor alludes to drawing resources, capabilities, and collective efforts inward, an act that benefits Indigenous communities through cultural diversity, knowledge systems, customs, and identity. Self-governance, cultural and language revitalization, and nation-building through Indigenous in- stitutions are core components of fire-keeping activities that would allow Indigenous communities to survive and flourish (Dell et al., 2017). These two metaphors provide a more culturally informed understanding of how Indigenous entrepreneurs negotiate economic and community-based cultural agendas in their entrepreneurial activities. The Indigenous entrepreneurial ecosystem lens can provide a starting point for moving toward a more holistic policy approach.

\section{Voices of Indigenous Entrepreneurs}

The findings from the present study confirmed the perspective from the literature (see Gallagher, 2015), indicating that Indigenous entrepreneurship is highly context-dependent and community-focused. In this study, there were differences in the scale, scope, and nature of the entrepreneurial activities of the participants, who operated either in the urban (Winnipeg) or rural (Churchill, Gillam, Thompson) contexts of Manitoba. Differences emerged even within the various rural contexts depending on the geographical particularities of the land. Despite those differences, common contextual themes emerged from the participants' stories that play a crucial role in creating a supportive ecosystem for Indigenous entrepreneurship. This article describes the three core themes that emerged from the present study, forming the foundation for an Indigenous entrepreneurial ecosystem approach: (a) relationships with the land and the community; (b) the relevance of education and appropriate training for life; and (c) the importance of cultural survival and self-determination. Those themes are introduced below to the reader through the voices of participants, showing how entrepreneurship and innovation are experienced and carried out by Indigenous entrepreneurs in their local contexts.

\section{Indigenous Voice: "We Were Gifted with the Beauty, the Landscape, the Animals!"}

This first theme reveals how Indigenous entrepreneurship is integrally connected and guided by the relationship with the land and the community. The geographical uniqueness of Churchill, advertised as "the polar bear country" (Town of Churchill, n.d.), has made this area a hotspot for tourism, providing employment to many In- 
digenous families. Although it is highly seasonal work, Indigenous entrepreneurs in Churchill are involved in providing guided tours where they take tourists out on the land to see polar bears, beluga whales, birds, or the Northern Lights. They organize dogsledding rides, offer bed and breakfast accommodations, or make handicrafts as souvenirs. A participant noted: "Any Indigenous that has a business here in Churchill..., they're connected to the land." Yet, this richness of land is not taken for granted. What makes Indigenous entrepreneurial activities distinct from others are these cultural teachings that are part of who they are as individuals. Several participants shared with me how they built deep personal connections with the land, integrating their cultural teachings into everyday activities: "I always have an offering of tobacco in my bag," "I spend time with whatever I harvest, and I thank that animal for giving itself to me." I was invited to a long conversation with a participant where he shared how he educated his tourists and visitors on the richness of land and on respectful behavior toward the living surroundings. He summarized: "I was always taught a great love and respect for animals, so that's what I tell my tourists." There are also many non-Indigenous tourism companies that operate in Churchill who tend to exploit the land and local people for profits. A participant commented:

I really don't like the fact that [name of the company] comes into this community with all their tourists and they try their hardest not to spend money here. They bring all their own gear, they bring all their own food, they bring their own wine. It's ridiculous. And then, all of their waste goes to our landfill and they're not taxed on it.

In an ecosystem approach, governments' role is to make sure there are business regulations in place that protect the Indigenous knowledge held by the community, so that activities are not exploitative or harmful and directly benefit the local community.

This deep connection with land guides the underlying philosophy of Indigenous entrepreneurship, whereby the economic benefit is often less important than the entrepreneurs' relationship with their community (Peredo \& Chrisman, 2006). While participants in this study recognized that "the currency of today is money," the dominant opinion emphasized the importance of community over profits. The following quote captures this idea:

It can't be always, you know, business first. I think I've succeeded because, giving back to my community is a heck of a lot more important... If you are very focused on the upcoming of the community, then you've got a chance.

A participant from Gillam, a more isolated town that is primarily a home to non-Indigenous Manitoba Hydro employees, described a similar approach with regards to supporting his community. His activities were smallscale and not focused on money-making. He reflected:

I'm always out on the land ... I do what I can to provide for my family. A lot of fishing, hunting, getting medicines. I sell my furs. I don't really sell any of the meat, fish, anything like that... I give a lot away for free to people who need it.

As the community in Gillam is small and many individuals were struggling with core necessities like food, his entrepreneurial activities were helping his community. The payback he got came from being valued and appreciated by others. This comment demonstrates the difference in perspectives whereby support for the community is more important than financial profits.

The urban context of Winnipeg had provided different opportunities to engage in entrepreneurial activities. The activities were often less driven by geographical characteristics, yet still were connected to the concept of space. A participant involved in design and architectural work shared with me how spaces can have healing qualities. The participant commented: "Designing spaces can be healing. You can create spaces where people are able to connect, like community spaces."

The participant reflected on the trauma experienced by her own close relatives as residential school survivors. These experiences had profoundly shaped the participant's entrepreneurial choices to become an architect and interior designer, pointing to the close connection of her work to her community.

These experiences from both urban and rural contexts show that the fire-keeping nature of Indigenous entrepreneurship is increasingly prominent in entrepreneurial activities and serves as the underlying rationale for many business activities. As such, an Indigenous ecosystem approach, driven by the Indigenous peoples, should be highly focused on the strength and well-being of the community before establishing programmatic supports with short-term benefits. 


\section{Indigenous Voice: "You Get Out of School and What Are You Really Prepared For?"}

This second theme emerging from the interviews captures the limited relevance of formal educational programs and their disconnect from Indigenous knowledges. While formal education was viewed as important, cultural knowledge was gained by physically being on the land and learning from elders. A participant in his thirties shared:

Old Randy was my mentor. I worked for him since I was about 13 years old ... I learned how to skin all the animals. I learned how, when to go out. Learned about ice. I learned about water. Being on the land or going through the ice, breaking through when getting stuck. He taught me everything.

This perspective does not always align with the programmatic and curriculum goals of a formal education and can lead to missing classes and dropping out of school. Most Indigenous entrepreneurs in this study did not complete high school. The study participants were largely self-taught, gaining knowledge by working with family members or mentors.

Without a formal diploma, entrepreneurial activities were often the only choice left for them. However, their limited skills in how to write grants and how to put together a business plan made it hard to succeed. People commented on the barriers they had faced and their regret for not completing formal schooling noting that "I made all the mistakes of not having a business education" and "[There is a need for] having someone to tell you what to do and how to do it and where to start." One commented:

I spent, probably, 60 hours on this idea writing the business plan and trying to figure out how to do all this stuff ... I got two-thirds of the way through the process and I said, you know what, this is just too much for me. I can't do this.

In several participants' experiences, it was apparent that systemic inequities involving colonial practices by non-Indigenous people had caused permanent dependencies on the dominant cultural group. In order to help their families, children typically worked as local tour guides for non-Indigenous customers, pointing them to the best hunting and fishing areas. A participant reflected:

They would come in and pay us. We'd take them out, and then they'd fly back to wherever they came from. We had a lot of guys from Minnesota, Wisconsin, and that area. A few guys from Texas, Florida ... My seasonal job carried into November. So, then I just didn't go [to school]. Then, the trapping started, so I just kept going.

As a result, children's education often gets interrupted early, they drop out of school, and are left at the mercy of their customers. With limited skills, they are suited only for seasonal or low-paying jobs, continuing to be dependent on their non-Indigenous wealthy clients. And the cycle keeps going.

Participants often questioned the relevance of the knowledge provided by the public schooling system. Indigenous youth make sense of the world around them by becoming grounded in Indigenous ways of being, connection with the land, traditions, and spirituality. However, standard provincial curricula often lack experiential culturally-informed land-based knowledge that would make school more meaningful to Indigenous youth. According to the experiences of the participants, their education was largely book-based, detached from actual life skills, and unengaging as is reflected in these quotes: "They taught you ancient history and math and stuff like this, but nothing about business" and "I just really hated school. And, yeah, I liked more real-life stuff."

Another participant from Churchill directly referred to the contextual nature of the life skills needed: "There could be more training in the fields, you know, teaching locals how to drive buggies, how to work in the tourism"; "Something in school needs to be done so that these kids know what steps to take to start a small business." Concerns over not taking advantage of the immediate surroundings to provide culturally relevant education were commonly expressed by the interviewees: "Rather than reading history in a book at school, history is over there, across the river. Why aren't they coming there, or even at Parks Canada, to start talking about it [local history]?"

While the Indigenous entrepreneurs primarily reflected on K-12 level education, the importance of post-secondary education also emerged in their stories. 
The only participant with a Master's degree noted: "Oh, [education plays] a huge role. I think that, for me, getting through my Master's degree in architecture, ughh, it was just, it was so tough. It was very, very tough." Several of the participants saw post-secondary education as a pathway to a better life for their children or grandchildren and proudly talked about their relatives who had gone to the city for university. There was a hope of overcoming the cultural divide once the children returned to their communities, so that in addition to formal education, they could gain a strong grounding in Indigenous ways of being as well.

\section{Indigenous Voice: "I Want to Hear the Young Drummers Here!"}

The third theme that emerged was the concern over cultural survival. Indigenous entrepreneurial activities serve as an important mechanism for strengthening one's cultural heritage, becoming a means for self-determination. A participant reflected: "Just to be able to do, you know, what my grandparents did, it just gives me a real sense of pride, you know, because that's who they were and that's who my people were, and it just really connects me back to my people, I find."

Several individuals specifically recognized their personal responsibility in carrying forward their grandparents' wisdom. Telling their story of cultural genocide was seen as giving purpose and meaning to their activities. One individual stated: "My people were just about destroyed ... Now, as a proud Sayisi Dene woman, I feel like I have an obligation to let the rest of the country, the rest of the world, know what has happened to my people."

One of the most crucial areas of attention for Indigenous cultural survival and self-determination was the involvement of Indigenous youth. Participants shared their stories about how they saw their kids as a link for passing on cultural knowledge. A father reflected on his relationship with his young daughter:

I take her out on the canoe with me to set nets. I take her out hunting, certain things, like hunting ducks or whatever she's able to come hunt ... When she's older, when she's my age, then she will be a provider. So, it will be her job to get food for her family, for the Elders, for other people in the community.
Another noted similarly the importance of carrying on knowledge through his children: "I just kind of want to, you know, keep that knowledge rolling and pass it on." One individual saw her role as bringing this constantly to the attention of community leaders: "I keep on stressing to my management that we really need to connect with the youth and the Elders."

There was a common agreement that more attention needed to be targeted toward the youth that live in local communities. Problems around mental health, various addictions, and leaving the community were mentioned as direct threats to cultural and economic survival. Those concerns were strongly expressed by a community leader: "We're tired of having our youth run away, or our youth not doing anything after they've graduated." This was recognized as a pressing issue that needs to be addressed by the government. One participant noted:

So that's what I really want to target is the youth, you know. I want, I want to hear the young drummers here, you know, I want to see them drumming... That's something that I would love to see one day.

Being active through entrepreneurship has allowed Indigenous individuals to establish themselves as a force in the economic realm in Canada. As governments are becoming more attentive toward the economic contributions of Indigenous peoples, Indigenous entrepreneurs are gradually gaining legitimacy and a stronger voice in this process of self-determination. A participant confirmed: "We're a self-governed nation, and we're an industrious people. Indigenous peoples support each other, you know, because we really want to use our own people."

Increasingly, Indigenous entrepreneurs are becoming involved in policy development, decision-making, and governance, creating a momentum around shifting the predominant narrative of what is regarded as innovation. The following is an example of increased involvement in setting one's own path through actively participating in policy work: "I'm chairing the Indigenous Tourism Advisory Committee for the province. So, we're announcing our initiative to our strategic plan, our threeyear plan to help Indigenous people get into business this year."

These examples show how intertwined the experiences of fire-seeking and fire-keeping activities are a reality. In order to be successful as an Indigenous entre- 
preneur, one needs the reassurance that the fire at home is being kept strong, so there is a community to return to. Supporting systemic initiatives (especially for youth entrepreneurs), such as facilitating networks, considering strategic partnerships, and establishing targeted mentorships, can strengthen the socio-cultural aspects of entrepreneurship that support the fire-keeping and fire-seeking activities in Indigenous communities.

\section{How Can Canada's Entrepreneurship and Innovation Policy Move Forward?}

Indigenous entrepreneurship has become an area of high importance to Canada. In moving forward, government policies should take a systematic decolonizing approach that supports the idea of an ecosystem, highlighting socio-cultural contexts associated with Indigenous entrepreneurship and innovation. As Dell and Houkamau (2016) argued, an Indigenous entrepreneurial ecosystem is composed of both actors and factors that form a complex holistic web of socio-cultural relationships, grounding the success of Indigenous entrepreneurship. In Canada, there is currently no shortage of various Indigenous-led organizational actors that form a core part of the Indigenous entrepreneurial ecosystem. Documents have reported over 150 organizations, including various non-profits and financial institutions (e.g., the Aboriginal Financial Officers Association, the Council for the Advancement of Native Development Officers, the National Organization of First Nation Lands Managers, and the Canadian Council for Aboriginal Business) (Idea Connector Network, n.d.). As demonstrated by the findings of this study, what is currently lacking is the factor aspect of the Indigenous ecosystem. That means that increased focus should be placed on the cultural component and on relationships with the land and the broader community in various supports associated with Indigenous entrepreneurship. Furthermore, higher education serves as an important factor in grounding Indigenous innovation in decolonizing approaches. Such an approach could counterbalance the current critique around the shortterm proposal- and program-based nature of government policies. When a community is strong and striving, and Indigenous values are considered, then there is a path for moving forward with entrepreneurial activities.
The cultural aspect of an Indigenous entrepreneurial ecosystem means questioning the dominant values that are ingrained in the Canadian innovation narrative. Policy documents have framed entrepreneurship and innovation narrowly through their commercialization promise. Such a framing pushes Indigenous communities to actively exploit their own lands and knowledges to live up to the Western standards. The mainstream innovation narrative largely overlooks the value of the land-based knowledge and learning from the land that are inherently grounded in Indigenous ways of knowing. As a result, those unique knowledges may be lost as they are not valued and not supported by policy. There is a need to rethink how Indigenous innovation is understood in $\mathrm{Ca}-$ nadian policy discourse. This new approach should be informed by a critical decolonizing lens that challenges the dominant values associated with entrepreneurship. Innovation in policy contexts needs to be re-imagined as a process of re-learning one's cultural traditions (including languages), and the vulnerability of Indigenous communities needs to be recognized. This study provided evidence on how Indigenous entrepreneurs are trying to balance their cultural heritage with economic benefits, often jeopardizing their futures by dropping out of school and opening their lands and resources to outside companies that drain resources from the community. Paying policy attention to different framings of innovation would help to create an environment where Indigenous cultural heritage can be protected and strengthened and, thus, to reframe Canada's innovation agenda.

Higher education institutions play a crucial role in this process. Large-scale programmatic and financial efforts to support Indigenous entrepreneurship should be targeted to youth, advancing their access to relevant (higher) education and skills training. As Indigenous entrepreneurship and innovation is grounded in Indigenous cultural and community connections, a cohort model of Indigenous entrepreneurial programs, led in collaboration with community leaders, is worth considering. The most pressing issue for educational institutions is to address the systemic inequalities that create barriers for Indigenous youth to break the cycle of continuous dependency on the dominant culture. Higher education institutions should pay attention to the composition of their programs and curriculum from strength-based perspectives and move toward normalizing Indigenous knowledges in the higher education context. Studies 
have shown an increase in entrepreneurial education programs and courses offered in Canadian $\mathrm{K}-12$ as well as post-secondary education institutions (Pinto \& Blue, 2015; Sá et al., 2014). However, the entrepreneurial programs offered to Indigenous high school students tend to reproduce dominant Western models of individual success, ignoring the socio-cultural context associated with Indigenous youth (Pinto \& Blue, 2015). Establishing community-based mentorship programs involving Indigenous entrepreneurs that show the value of Indigenous entrepreneurship and innovation would help strengthen the career paths for Indigenous youth. Providing supports to youth-led initiatives and encouraging decolonizing approaches to education and skills-training among non-Indigenous faculty, administrators, and staff could help highlight viable paths to employment. Skills training for adults also plays a significant role in supporting Indigenous entrepreneurship.

There is a lot that Canada can learn from Indigenous communities regarding their relationships to the land, to other individuals, and to their community. Provincial and federal governments have the responsibility and opportunity to support and protect Indigenous knowledges as an essential part of Indigenous entrepreneurship. The next phase of the innovation agenda is to address the structures that reinforce dominant narratives of what counts as entrepreneurship or what is seen as valid innovation. Shifting the policy paradigm toward alternative ways of understanding innovation may ultimately help to carve a path toward unpacking the complex societal and environmental problems that Canada and the wider world are grappling with today.

\section{References}

Agrawal, A. (1995). Dismantling the divide between indigenous and scientific knowledge. Development and Change, 26(3), 413-439. https://doi. org/10.1111/j.1467-7660.1995.tb00560.x

Anderson, R. B., Dana, L. P., \& Dana, T. E. (2006). Indigenous land rights, entrepreneurship, and economic development in Canada: "Opting-in" to the global economy. Journal of World Business, 41(1), 45-55. https://doi.org/10.1016/j.jwb.2005.10.005

APTN National News. (2017, August 28). Ottawa splits Indigenous Affairs into two departments. https://apt- nnews.ca/2017/08/28/ottawa-splits-indigenous-affairs-into-two-departments

Battiste, M., \& Youngblood, J. (2000). Protecting Indigenous knowledge and heritage: A global challenge. UBC Press.

Bill-41: Declaration on the Rights of Indigenous Peoples Act. (2019). 41st Parliament, 4th Session, British Columbia Parliament. https://www.leg.bc.ca/parliamentary-business/legislation-debates-proceedings/41st-parliament/4th-session/bills/first-reading/ gov41-1

Borrás, S., \& Edquist, C. (2014). Innovation policy for knowledge production and R\&D: The investment portfolio approach (No. 2014/21). Lund University, CIRCLE-Center for Innovation, Research and Competences in the Learning Economy. https://ideas. repec.org/p/hhs/lucirc/2014 021.html

Canadian Council for Aboriginal Business (CCAB). (2016). Promise and prosperity: The 2016 Aboriginal business survey. https://www.ccab.com/wp-content/ uploads/2016/10/CCAB-PP-Report-V2-SQ-Pages.pdf

Colbourne, R. (2017). Indigenous entrepreneurship and hybrid ventures. In A. C. Corbett \& J. A. Katz (Eds.), Hybrid ventures (pp. 93-149). Emerald Publishing Limited.

Croce, F. (2017). Contextualized Indigenous entrepreneurial models: A systematic review of Indigenous entrepreneurship literature. Journal of Management \& Organization, 23(6), 886-906. https://doi. org/10.1017/jmo.2017.69

Curry, J., Donker, H., \& Krehbiel, R. (2009). Development corporations in aboriginal communities: The Canadian experience. Journal of Developmental Entrepreneurship, 14(01), 1-19. https://doi. org/10.1142/S1084946709001119

Daes, E. I. A. (1994). Equality of Indigenous peoples under the auspices of the United Nations Declaration on the Rights of Indigenous Peoples. Thomas L. Review, 7, 493.

Darisi, T., \& Watson, L. (2017). Strengthening youth entrepreneurship education: An evaluation and best practices report. Openly. http://changeopenly.com/ wp-content/uploads/2017/10/Openly-Strengthen- 
ing-Youth-Entrepreneurship-Education-Web-Links. pdf

Dell, K. M., \& Houkamau, C. A. (2016, December 6-9). Fire keepers and fire seekers: $A$ dual entrepreneurial strategy for developing indigenous economies in a globalized world [Paper presentation]. 30th Australian and New Zealand Academy of Management Conference, Brisbane, Australia. https://www.anzam. org/wp-content/uploads/pdf-manager/2815 ANZAM2016-290-FILE001.PDF

Dell, K. M., Mika, J. P., \& Warren, L. (2017). Indigenous entrepreneurial ecosystems: A New Zealand perspective. Academy of Management Proceedings, 2017. https://doi.org/10.5465/ AMBPP.2017.16725abstract

Department of Justice, Canada. (2018). Principles: Respecting the Government of Canada's relationship with Indigenous peoples. https://www.justice.gc.cal eng/csj-sjc/principles.pdf

Donald, D. (2009). Forts, curriculum, and Indigenous Métissage: Imagining decolonization of Aboriginal-Canadian relations in educational contexts. First Nations Perspectives, 2(1), 1-24. https://mfnerc.org/ resources/fnp/

Expert Panel on the State of Science and Technology and Industrial Research and Development in Canada. (2018). Competing in a global knowledge economy: The current state of $R$ and $D$ in Canada. Council of Canadian Academies (CCA). http:/l new-report.scienceadvice.ca

Gallagher, B. M. (2015). Entrepreneurship and Indigenous identity: Three studies on the connections between Indigenous identity and entrepreneurial practices in Canada and Australia (Publication ID: etd8866) [Doctoral dissertation, Simon Fraser University]. Simon Fraser University Summit Institutional Repository. http://summit.sfu.ca/item/14967

Gallagher, B. M., \& Selman, M. (2015). Warrior entrepreneur. The American Indian Quarterly, 39(1), 73-94. https://doi.org/10.5250/amerindiquar.39.1.0073

Global Affairs Canada. (2019). Canada's state of trade 2019. https://www.international.gc.ca/gac-amc/assets/pdfs/publications/State-of-Trade-2019 eng.pdf
Government of Canada. (n.d.). Strategic partnerships initiative: Overview. https://www.aadnc-aandc.gc.cal eng/1330016561558/1330016687171

Government of Canada. (1989). Gathering strength: Canada's Aboriginal action plan. http://www.inac.gc.ca

Government of Canada. (2009). Federal framework for Aboriginal economic development. https://www.aadnc-aandc.gc.ca/DAM/DAM-INTER-HQ/STAGING/ texte-text/ffaed1 1100100033502 eng.pdf

Government of Canada. (2018). Key priority: Economic prosperity. https://www.sac-isc.gc.cal eng/1523818136138/1523818153427

Government of Canada. (2019a). Budget 2019 highlights: Indigenous and Northern investments. https://www.aadnc-aandc.gc.cal eng/1553716166204/1553716201560

Government of Canada. (2019b). Building a nation of innovators. https://www.ic.gc.ca/eic/site/062.nsf/ eng/h 00105.html

Hindle, K., \& Lansdowne, M. (2005). Brave spirits on new paths: Toward a globally relevant paradigm of Indigenous entrepreneurship research. Journal of Small Business \& Entrepreneurship, 18(2), 131-141. https://doi.org/10.1080/08276331.2005.1 $\underline{0593335}$

Hindle, K., \& Moroz, P. (2010). Indigenous entrepreneurship as a research field: Developing a definitional framework from the emerging canon. International Entrepreneurship and Management Journal, 6(4), 357-385. https://doi.org/10.1007/s11365-009-0111-x

Hindle, K., Moroz, P., \& Anderson, R. (2007). Defining Indigenous entrepreneurship as a research field: Discovering and critiquing the emerging canon. Frontiers of Entrepreneurship Research, 27(9), 1-16. http://www.kevinhindle.com/publications/ K4.2007\%20Babson\%20Indig\%20Eship\%20Canon. pdf

Huaman, E. S. (2017). Indigenous-minded innovation in shifting ecologies. In E. S. Huaman \& B. Sriraman (Eds), Indigenous innovation: Universalities and peculiarities (pp. 1-11). Sense Publishers.

Idea Connector Network (ICN). (n.d.). A framework for 
creating a national Indigenous women entrepreneurs ecosystem. http://ideaconnector.net/wp-content/uploads/2018/04/ECOSYSTEM-Framework-Report-18-May-2018-R.pdf

Imas, J. M., Wilson, N., \& Weston, A. (2012). Barefoot entrepreneurs. Organization, 19(5), 563-585. https://doi.org/10.1177/1350508412459996

Indigenomics Institute. (n.d.). 100 billion. http://indigenomicsinstitute.com/100-billion/

Indigenous Tourism Association of Canada (ITAC). (2019). Accelerating Indigenous tourism growth in Canada: Five-year strategic plan update 2019-2024. https://indigenoustourism.ca/corporate/wp-content/uploads/2019/03/18-10-Accelerating-Tourism-Growth-Booklet-v7.pdf

Information and Communication Technology Council (ICTC). (2017). Digital economy annual review 2017. https://www.ictc-ctic.ca/wp-content/uploads/2018/02/ICTC-Annual-Review-2017-EN.pdf

Isenberg, D. J. (2010). How to start an entrepreneurial revolution. Harvard Business Review, 88(6), 40-50. https://doi.org/10.2307/256548

Kayseas, B., Hindle, K., \& Anderson, R. B. (2006). Fostering Indigenous entrepreneurship: A case study of the Membertou First Nation, Nova Scotia, Canada. In IIBEC 2006: Proceedings of the 2006 international Indigenous business and entrepreneurship conference (pp. 1-25). IIBEC.

Kirmayer, L. J., Brass, G. M., Holton, T., Paul, K., Simpson, C., \& Tait, C. (2007). Suicide among Aboriginal people in Canada. The Aboriginal Healing Foundation. http://www.ahf.ca/downloads/suicide.pdf

Lindsay, N. J. (2005). Toward a cultural model of Indigenous entrepreneurial attitude. Academy of Marketing Science Review, 1-15. http://www.amsreview. org/articles/lindsay05-2005.pdf

Lowan-Trudeau, G. (2012). Methodological métissage: An interpretive Indigenous approach to environmental education research. Canadian Journal of Environmental Education (CJEE), 17, 113-130. https:// cjee.lakeheadu.ca/article/view/1082/662

Lundvall, B. A. (2009). Innovation as an interactive process: User-producer interaction to the national system of innovation: Research paper. African Journal of Science, Technology, Innovation and Development, 1, 10-34. https://library.oapen. org/bitstream/id/0acd2718-684c-4a76-8087-2aecf5235612/626406.pdf\#page=78

Manimala, M. J., \& Wasdani, K. P. (2015). Emerging economies: Muddling through to development. In M. J. Manimala, K. Wasdani, \& B. Gnanakumar (Eds.), Entrepreneurial ecosystem: Perspectives from emerging economies (pp. 3-53). Springer.

National Aboriginal Capital Corporation (NACCA). (2017). Aboriginal entrepreneurship in Canada. https://nacca.ca/report-shows-aboriginal-entrepreneurs-face-significant-barriers-in-financial-ecosystem/

National Indigenous Economic Development Board (NIEDB). (2019). The Indigenous economic progress report. http://www.naedb-cndea.com/wp-content/uploads/2019/06/NIEDB-2019-Indigenous-Economic-Progress-Report.pdf

Organisation for Economic Co-operation and Development. (2019). Linking Indigenous communities with regional development: Policy highlights. http://www. oecd.org/regional/Indigenous-Communities-Policy-Highlights.pdf

Patzer, J. (2019). Indigenous rights and the legal politics of Canadian coloniality: What is happening to free, prior and informed consent in Canada? The International Journal of Human Rights, 23(1-2), 214-233. https://doi.org/10.1080/13642987.2018.1562915

Peredo, A. M., Anderson, R. B., Galbraith, C. S., Honig, B., \& Dana, L. P. (2004). Towards a theory of Indigenous entrepreneurship. International Journal of Entrepreneurship and Small Business, 1(1-2), 1-20. https://doi.org/10.1504/IJESB.2004.005374

Peredo, A. M., \& Chrisman, J. J. (2006). Toward a theory of community-based enterprise. Academy of Management Review, 31(2), 309-328. https://doi. org/10.5465/amr.2006.20208683

Pinto, L. E., \& Blue, L. E. (2015). Pushing the entrepreneurial prodigy: Canadian Aboriginal entrepreneurship education initiatives. Critical Studies in 
Education, 57(3), 358-375. https://doi.org/10.1080/1 7508487.2015.1096291

Pinto, L. E., \& Blue, L. E. (2017). Aboriginal entrepreneurship financing in Canada: Walking the fine line between self-determination and colonization. Journal of Entrepreneurship in Emerging Economies, 9(1), 2-20. https://doi.org/10.1108/JEEE-102015-0059

Roundy, P. T., Bradshaw, M., \& Brockman, B. K. (2018). The emergence of entrepreneurial ecosystems: A complex adaptive systems approach. Journal of Business Research, 86, 1-10. https://doi. org/10.1016/j.jbusres.2018.01.032

Sá, C. M., Kretz, A., \& Sigurdson, K. (2014). The state of entrepreneurship education in Ontario's colleges and universities. Higher Education Quality Council of Ontario. http://www.heqco.ca/en-ca/Research/ ResPub/Pages/The-State-of-Entrepreneurship-Education-in-Ontario-s-Colleges-and-Universities.aspx

Schumpeter, J. A. (1934). The theory of economic development: An inquiry into profits, capital, credit, interest, and the business cycle. Harvard University Press.

Schwanen, D. (2017). Innovation policy in Canada: A holistic approach (Commentary No. 497). CD Howe Institute. https://cdhowe.org/intelligence-memos/ daniel-schwanen-canada-needs-broader-approach-fostering-innovation

Shoebridge, A., Buultjens, J., \& Peterson, L. S. (2012). Indigenous entrepreneurship in northern NSW, Australia. Journal of Developmental Entrepreneurship, 17(03), 1250017-1-1250017-31. https://doi. org/10.1142/S1084946712500173

Sengupta, U., Vieta, M., \& McMurtry, J. J. (2015). Indigenous communities and social enterprise in Canada. Canadian Journal of Nonprofit and Social Economy Research, 6(1), 104-123. https://doi.org/10.22230/ cjnser.2015v6n1a196

Stam, E. (2015). Entrepreneurial ecosystems and regional policy: A sympathetic critique. European Planning Studies, 23(9), 1759-1769. https://doi.org/ $\underline{10.1080 / 09654313.2015 .1061484}$

Statistics Canada. (2016). Aboriginal peoples: Fact sheet for Manitoba. https://www150.statcan.gc.cal n1/pub/89-656-x/89-656-x2016008-eng.htm

Statistics Canada. (2019). First Nations people, Métis and Inuit in Canada: Diverse and growing populations. https://www150.statcan.gc.ca/n1/pub/89-659x/89-659-x2018001-eng.htm

Tedmanson, D., Verduyn, K., Essers, C., \& Gartner, W. B. (2012). Critical perspectives in entrepreneurship research. Organization, 19(5), 531-541. https://doi. org/10.1177/1350508412458495

Town of Churchill. (n.d.). Safety in polar bear country [Visitor's pamphlet]. https://churchill.municipalwebsites.ca/Editor/images/Documents/PolarBearSafetyChurchillE1Final\%20Combined\%20print.pdf

United Nations. (2007, September 13). United Nations Declaration on the Rights of Indigenous Peoples (UNDRIP). https://www.un.org/development/desal indigenouspeoples/declaration-on-the-rights-of-indigenous-peoples.html

Van Praag, C. M., \& Versloot, P. H. (2007). What is the value of entrepreneurship? A review of recent research. Small Business Economics, 29(4), 351-382. https://doi.org/10.1007/s11187-007-9074-x

Warren, L., Mika, J., \& Palmer, F. (2017). How does enterprise assistance support Māori entrepreneurs? An identity approach. Journal of Management \& Organization, 23(6), 873-885. https://doi.org/10.1017/ imo.2017.73

Wuttunee, W. (2004). Living rhythms: Lessons in Aboriginal economic resilience and vision. McGill-Queen's University Press.

\section{Contact Information}

Merli Tamtik

merli.tamtik@umanitoba.ca

\section{Notes}

1 I would like to express deep gratitude for the gift received from the Indigenous individuals who graciously agreed to share their time and engage in these conversations. 
I would also like to thank the blind reviewers for their insightful comments, guidance, and area expertise in shaping this article. This work was funded by a SSHRC IDG grant.

2 The governments' initial financial support has been yielding results, as Canada has been recognized as a leader in its Strategic Partnership Initiative in Canada that coordinates federal investment to maximise opportunities for Indigenous business and employment participation (Organisation for Economic Co-operation and Development, 2019). One example of this is the Louis Riel Capital Corporation (LRCC), a Manitoba-based Metis-owned lending institution initially funded by the Government of Canada under its 2009 Canadian Aboriginal Economic Development Strategy. 